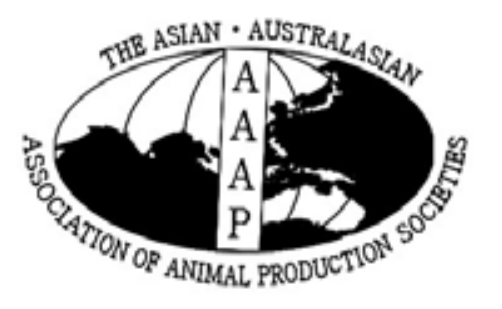

Asian-Aust. J. Anim. Sci.

Vol. 20, No. 1 : 124 - 131

January 2007

www.ajasinfo

\title{
Endocrine Aspects of Oestrous Cycle in Buffaloes (Bubalus bubalis): An Overview
}

\author{
S. Mondal*, B. S. Prakash and P. Palta \\ National Dairy Research Institute, Karnal, Haryana-132 001, India
}

\begin{abstract}
There is worldwide interest in buffalo as an animal for meeting the growing demands of meat, milk and work in the developing countries. One of the major constraints to full exploitation of the productive potential of buffalo has been its inherently low reproductive efficiency as reflected by late maturity, poor expression of oestrus, silent oestrus, irregular oestrous cyclicity, seasonality in breeding, anoestrus, low conception rate, long postpartum interval, repeat breeding etc. Ovarian cyclicity is regulated by endocrine and neuroendocrine mechanisms namely hypothalamic hormones, gonadotropins and ovarian steroids. Detailed endocrine investigations are suggested with special reference to the hypothalamo-hypophysial-ovarian axis to gain a better understanding of reproduction in buffalo and to modify it to derive the maximum benefit from this animal. (Key Words : Buffalo, Gonadotropins, Ovarian Steroids, Reproductive Efficiency)
\end{abstract}

\section{INTRODUCTION}

Buffalo has recently gained a lot of attention due to its high milk yield with high fat percentage, tolerance to hot and humid climate, lean meat, draught ability and a reasonable growth rate on roughage feeding. Buffalo, as a domestic animal with its predominant home tract in South East Asia and Mediterranean, has found great acceptance in the rural economies of Asia and Africa. Some peculiar problems of this species viz. late maturity, silent heat coupled with poor expression of oestrus, irregular oestrous cyclicity, seasonality in breeding, anoestrus, low conception rate, long postpartum interval and repeat breeding etc. have been the major constraints leading to low productivity (Madan et al., 1993; 1996). Since an understanding of the hormonal interplay is essential for alleviating reproductive problems of endocrine origin, a considerable attention has been focused in the last two decades on utilizing reproductive endocrinology as a means to identify problems specific to this species and to devise means for augmenting its reproductive performance.

The different phases of reproductive cycle are regulated by intricate sequential events and interactions between hypothalamic releasing hormones, hormones secreted from

\footnotetext{
* Corresponding Author: S. Mondal. Division of Physiology and Climatology, Indian Veterinary Research Institute, Izatnagar, Bareilly-243 122, Uttar Pradesh, India.

Received August 12, 2005; Accepted March 17, 2006
}

the pituitary and sex steroids secreted by the ovary. Lack of integration or synchronization or endocrine imbalances at any phase of the sequence may result in reproductive failure. A sound knowledge of reproductive functioning in terms of interplay of hypothalamic, gonadotropic and gonadal hormones, with synergistic and antagonistic influences from other hormones and factors involved in the regulation of various reproductive stages, accurate oestrus detection, timely pregnancy diagnosis and early detection of nonconceived stock can be expected to lead to an improvement of the reproductive efficiency. Oestrus detection is difficult in this species due to lack of expert personnel, high prevalence of silent oestrus, poor expressions of behavioural oestrus symptoms and a wide variation in the duration of oestrus. This review is focused on the information available on the profiles of peripheral circulatory concentrations of various hormones associated directly or indirectly with reproduction during oestrous cycle in buffalo.

\section{ENDOCRINOLOGY OF OESTROUS CYCLE}

\section{Progesterone}

A perusal of the studies reported on peripheral progesterone concentrations during oestrous cycle in buffalo (Kamonpatana et al., 1976; Ahmed et al., 1977; Bachalaus et al., 1979; Batra et al., 1979; Rao and Pandey, 1982; Jainuddin et al., 1983; Pahwa and Pandey, 1983; 
Kanai and Shimizu, 1984; Shah and Mehta, 1992; Kamboj and Prakash, 1993; Mondal et al., 2001a; Mondal and Prakash, 2002a; Mondal and Prakash, 2002b, c; Mondal et al., 2003a) indicates that peripheral plasma progesterone profile in buffalo is very similar to that in cattle (Wetteman et al., 1972). Progesterone levels rise and fall in coincidence with the growth and regression of corpus luteum (CL) since $\mathrm{CL}$ is the source of progesterone in cycling buffalo (Ahmed et al., 1977). Peripheral progesterone concentrations are minimal on the day of oestrus $(0.1 \mathrm{ng} / \mathrm{ml})$, rise to peak concentrations of $1.6-3.6 \mathrm{ng} / \mathrm{ml}$ on days 13 to 15 of the cycle (Ahmed et al., 1977; Bachalaus et al., 1979) or even on day 17 (Pahwa and Pandey, 1983) before declining to basal levels at the onset of next oestrus. Progesterone levels continue to increase in animals that conceive but drop 3 days before the next oestrus in those that fail to conceive (Batra et al., 1979). The onset of the decline in progesterone concentrations is variable, depending upon the time of regression of CL. When progesterone concentrations were compared in buffaloes which exhibit silent and those which showed overt oestrus, (Mondal and Prakash, 2002b) found that progesterone concentrations increased from $0.42 \pm 0.02$ and $0.38 \pm 0.02 \mathrm{ng} / \mathrm{ml}$ during perioestrus phase (day- 1 to day 1 , day $0=$ day of oestrus) to $0.66 \pm 0.12$ and $0.51 \pm 0.07 \mathrm{ng} / \mathrm{ml}$ during early luteal phase (day 2 to day 5) and then further to $1.55 \pm 0.33$ and $1.30 \pm 0.13 \mathrm{ng} / \mathrm{ml}$ during mid-luteal phase (day 6 to day 14) following which these declined to $1.12 \pm$ 0.27 and $0.66 \pm 0.13 \mathrm{ng} / \mathrm{ml}$ during late luteal phase (day -4 to day -2) in buffaloes that exhibited overt oestrus and silent oestrus, respectively.

Significant differences, which have been found in the weight of the CL, its progesterone concentration and content among different phases of oestrous cycle parallel those observed in the peripheral circulatory progesterone concentrations. CL weight has been reported to increase progressively from $605 \mathrm{mg}$ on day 3 to $1,885 \mathrm{mg}$ on day 13 followed by a decline to $1,292 \mathrm{mg}$ on day 18 of the cycle whereas progesterone concentration, which was $34.5 \mu \mathrm{g} / \mathrm{mg}$ on day 3 rose to $62 \mu \mathrm{g} / \mathrm{mg}$ on day 13 and then declined to $32.3 \mu \mathrm{g} / \mathrm{mg}$ on day 18 (Memon et al., 1971). The CL extract progesterone concentrations have been reported to increase from $7.27 \pm 0.95 \mu \mathrm{g} / \mathrm{mg}$ during stage-I of oestrous cycle (days $1-4$ ) to $8.98 \pm 0.67 \mu \mathrm{g} / \mathrm{mg}$ during stage-II (days 5-10) and then further to the highest concentrations of $11.44 \pm 1.42$ $\mu \mathrm{g} / \mathrm{mg}$ during stage-III (days 11-17) and then decline to $3.99 \pm 0.71 \mu \mathrm{g} / \mathrm{mg}$ during the stage-IV of oestrous cycle (days 18-20, Mondal et al., 2004b).

Lower progesterone levels at oestrus as well at midluteal phase in hotter $(0.14 \pm 0.05$ and $2.05 \pm 1.16 \mathrm{ng} / \mathrm{ml}$, respectively) than in cooler months $(0.49 \pm 0.06$ and $3.11 \pm$ $0.20 \mathrm{ng} / \mathrm{ml}$, respectively) are believed to be responsible for the poor expression of oestrus and low conception rate during summer season by some authors (Rao and Pandey, 1982). Others have, however, observed progesterone concentrations to be significantly higher during summer compared to those in winter season (Mondal et al., 2001a; 2004a). Progesterone concentrations of ovarian follicular fluid have also been reported to be lowest in monsoon (July to Oct) and highest in summer (March to June). A significant increase in peripheral plasma progesterone concentrations during prolonged heat exposure could be from a stress-induced rise in progesterone from adrenal cortex (Gwazdauskas et al., 1972; Wagner et al., 1972; Abilay et al., 1975). Progesterone concentrations have also been found to vary with the nutritional status. Progesterone concentrations have been reported to remain at lower levels in summer than in winter in buffaloes provided optimum nutrition compared to underfed ones (Kaur and Arora, 1984). Whereas the former exhibited weak oestrus of short durations during night hours in summer, the latter did not exhibit any oestrus. Thus, suboptimal nutrition coupled with stress due to high environmental temperatures may be responsible for long anoestrus in buffaloes.

The pattern of progesterone concentrations in milk has been found to be similar to that in plasma, although the concentrations in milk are much higher than those in plasma (Kamboj and Prakash, 1993). The average concentration of progesterone in milk, which was $0.5 \mathrm{ng} / \mathrm{ml}$ at oestrus increased to $18 \mathrm{ng} / \mathrm{ml}$ on day 15 and declined thereafter to $4.4 \mathrm{ng} / \mathrm{ml} 3$ days preceding the next oestrus in non pregnant buffaloes (Batra et al., 1979).

Progesterone concentrations in ovarian follicular fluid are much higher than those in peripheral circulation (Prakash et al., 1997; Palta et al., 1998c). Palta et al. (1998a) reported that progesterone concentrations $(\mathrm{pmol} / \mathrm{ml})$ were not related to follicular diameter and were not different among small (330.99 \pm 27.32$)$, medium (384.84 \pm 26.20$)$ and large follicles $(253.25 \pm 32.23)$.

\section{Oestradiol}

Peripheral plasma oestradiol profile in buffalo is not very different from that reported in cattle, with peak concentrations observed before and during the preovulatory surge of gonadotropins after which the levels come down to base values in the next few days, with minor fluctuations throughout the oestrous cycle. Bachalaus et al. (1979) observed a peak oestradiol concentration of $35.8 \mathrm{pg} / \mathrm{ml}, 1$ day before oestrus, with levels declining to $17.8 \mathrm{pg} / \mathrm{ml}$ when the first signs of behavioural oestrus were observed and then further to basal concentrations of $5.7 \mathrm{pg} / \mathrm{ml}$ within 2 days after oestrus. During the luteal phase, a minor peak of $10 \mathrm{pg} / \mathrm{ml}$ and a more sustained peak of $20 \mathrm{pg} / \mathrm{ml}$ were observed on days 4-5 and day 10 after oestrus. Others (Batra and Pandey, 1982, 1983; Pahwa and Pandey, 1983; Samad et al., 1988; Kumar et al., 1991) also reported that 
the concentration of oestradiol-17 $\beta$ increased following luteolysis and reached its peak value of 30-35 pg/ml either a day before or on the day of oestrus, after which these declined to $5-10 \mathrm{pg} / \mathrm{ml}$ within 2 days following oestrus. Thereafter, oestradiol concentrations fluctuates at lower levels throughout the luteal phase of the cycle, except on days 4 and 10 when minor peaks of $10-20 \mathrm{pg} / \mathrm{ml}$ were recorded. These minor peaks might have resulted from waves of follicular growth since buffaloes have been reported to undergo two or three waves of follicular growth during the oestrous cycle, with the second wave occurring during days 10-11 of the cycle (Baruselli et al., 1997; Manik et al., 1998). The prooestrus rise of oestradiol may be associated with triggering of $\mathrm{LH}$ release by positive feedback on hypothalamo-hypophyseal axis (Batra and Pandey, 1982, 1983).

In Swamp buffaloes, oestradiol-17ß profile during the oestrous cycle is more or less similar to that in the riverine buffaloes, but the overall concentrations have been reported to be lower in Swamp buffaloes. Peripheral plasma oestradiol concentrations of $2.9 \mathrm{pg} / \mathrm{ml}$ in the luteal phase and of 9.0-13.0 pg/ml at oestrus in Swamp buffaloes (Kanai and Shimizu, 1984; Avenell et al., 1985) were lower compared to higher values of $31.3 \pm 1.7 \mathrm{pg} / \mathrm{ml}$ at corresponding stages in Murrah buffaloes (Batra and Pandey, 1982, 1983).

Whole milk oestradiol-17 $\beta$ concentrations have been reported to be higher and positively correlated with those in plasma during oestrous cycle in buffaloes (Batra et al., 1980; Batra and Pandey, 1982, 1983). Whereas mean oestradiol concentrations vary between $20-25 \mathrm{pg} / \mathrm{ml}$ during the mid-luteal phase, at oestrus, these increase to $45-50$ $\mathrm{pg} / \mathrm{ml}$ (Batra and Pandey, 1982/83). The higher levels of oestradiol in milk than in plasma raises the question whether mammary gland is active in the uptake of oestradiol-17 $\beta$ or whether the synthesis of hormone takes place partly in the mammary tissue also. The ovarian follicular fluid oestradiol-17 $\beta$ concentrations are manifold higher than those in peripheral circulation (Palta et al., 1996a; 1998c). Oestradiol-17 $\beta$ concentrations (pmol/ml) have been reported to be positively related to follicular diameter and to be significantly higher in large (118.46 \pm $30.25)$ compared to those in medium follicles $(50.32 \pm 8.29)$ which, in turn had higher oestradiol than the small follicles (19.70 \pm 5.57 , Palta et al., 1998a). Parmar and Mehta (1994), however, reported that the medium sized follicles contained significantly higher oestradiol-17 $\beta$ compared to small and large follicles.

Plasma oestradiol concentrations are also affected by climate. When oestradiol concentrations were compared among hot-dry (April to June), hot-humid (July to September), warm (October to December) and cold (January to March) seasons, oestradiol concentrations were found to be lower in summer compared to cooler months (Rao and Pandey, 1983). Lower peak values of oestradiol around oestrus coupled with decreased progesterone concentrations was attributed to be the major reason responsible for a higher incidence of silent oestrus during summer by Rao and Pandey (1982).

\section{Inhibin}

Inhibin, a glycoprotein hormone produced by granulosa cells of ovarian follicles, suppresses hypophysial production and/or secretion of gonadotropins preferentially follicle stimulating hormone (FSH) through negative feedback at pituitary level (Burger, 1992). In an early study, Palta et al. (1996b) reported that peripheral plasma concentrations of immunoreactive inhibin (ir-inhibin) fluctuated between $0.40 \pm 0.07$ and $0.67 \pm 0.13 \mathrm{ng} / \mathrm{ml}$, without any pattern, during the oestrous cycle in buffaloes in summer season. However, in the winter season a clear pattern was observed in the peripheral ir-inhibin concentrations which were lowest $(0.35 \pm 0.02 \mathrm{ng} / \mathrm{ml})$ during the mid-luteal phase of estrous cycle (day 6 to day 14) increased significantly to $0.47 \pm 0.04$ $\mathrm{ng} / \mathrm{ml}$ during the late luteal phase (day -4 to day -2) and then further to $0.52 \pm 0.03 \mathrm{ng} / \mathrm{ml}$ during the perioestrus phase (day -1 to day 1 ). Ir-inhibin concentrations then decreased further to $0.40 \pm 0.03 \mathrm{ng} / \mathrm{ml}$ during the early luteal phase (day 2 to day 5, Palta et al., 1997).

A comparison of the circulating ir-inhibin concentrations between summer and winter seasons indicated that ir-inhibin concentrations were significantly higher in the late luteal and perioestrus phases during the winter season compared with corresponding periods during the summer season suggesting that environmental heat stress can cause a reduction in peripheral ir-inhibin concentrations, probably by adversely affecting follicular growth (Palta et al., 1997). A significant increase in inhibin levels through late luteal to perioestrus phase is suggestive of a vital role of inhibin in folliculogenesis (Mondal et al., 2000a; 2001b). A negative correlation between ir-inhibin and FSH indicated that inhibin is involved in folliculogenesis by negative feedback effects on FSH secretion in buffalo (Mondal et al., 2000b). Peripheral irinhibin concentrations were negatively correlated with peripheral progesterone concentrations in buffaloes indicating that corpus luteum is not a source of peripheral inhibin in buffaloes (Mondal et al., 2000a; Mondal et al., 2003a). In studies in which peripheral plasma ir-inhibin concentrations were compared between buffaloes which exhibited overt oestrus and those which had silent estrus reported that plasma ir-inhibin levels were significantly higher in buffaloes that exhibited silent oestrus indicating that this could be one of the reasons responsible for poor expression of oestrus (Mondal et al., 2002a, b; 2003b)

As also in case of cattle, the ovarian antral follicles are 
the primary source of inhibin in buffalo. Ir-inhibin concentrations have been reported to show a positive relationship with follicular diameter and to be significantly higher in follicular fluid from medium and large follicles $(8.44 \pm 0.54$ and $7.70 \pm 0.45 \mu \mathrm{g} / \mathrm{ml}$, respectively) in comparison to that from small follicles $(5.74 \pm 0.80 \mu \mathrm{g} / \mathrm{ml}$, Palta et al., 1996c). The total ir-inhibin content was highly correlated with the follicular diameter and although the irinhibin content was higher in large $>$ medium $>$ small follicles, a substantial part of peripheral inhibin could be coming from small and medium follicles. As the population of the follicles of all size categories contributes to the circulating inhibin levels, the pattern of peripheral ir-inhibin concentrations observed in the studies mentioned above is probably a reflection of the overall follicular population at different stages of oestrous cycle.

A positive correlation has been reported between follicular fluid ir-inhibin and oestradiol-17 $\beta$ in medium and large but not in small follicles by Palta et al. (1998b) who attributed it to a concomitant progressive increase in the capability of granulosa cells to produce inhibin and estradiol-17 $\beta$ during follicular growth and development. A non-significant relationship between follicular fluid inhibin and progesterone in small and medium follicles and a negative correlation in large follicles suggested that the intrafollicular production of progesterone was not associated with inhibin production during initial stages of growth and development of follicles.

\section{Follicle stimulating hormone}

Peripheral plasma FSH concentrations have been reported to be highest on the day of oestrus, with reported peak concentrations ranging from 52.9 (Heranjal et al., 1979a) to $57.9 \mathrm{ng} / \mathrm{ml}$ (Galhotra et al., 1985). Thereafter, the levels decline gradually and then fluctuate at basal values reported to range from $8.24 \pm 4.50$ to $16.6 \pm 5.74 \mathrm{ng} / \mathrm{ml}$ (Galhorta et al., 1985) to $20.7-29.6 \mathrm{ng} / \mathrm{ml}$ (Heranjal et al., 1979a) before rising again to peak levels at the next oestrus. After the occurrence of simultaneous pre-ovulatory surges of FSH and LH, LH levels decline sharply to the basal levels whereas FSH concentrations show a gradual decline (Kaker et al., 1980). A second FSH peak has not been demonstrated in buffaloes probably because of blood sampling has not been done at a frequency high enough to detect it in any of the studies.

Peripheral FSH concentrations are also influenced by climate. FSH concentrations have been reported to be significantly higher at oestrus and during the luteal phase in peak breeding seasons (November to December) in comparison to corresponding phases of medium (July to October) and low breeding season (March to June) in Surti buffaloes (Janakiraman et al., 1980). The FSH/LH ratio was higher during the peak breeding season compared to those in the medium and low breeding periods. In another study, the peak FSH concentrations on the day of oestrus were found to be similar during hotter and cooler months (Razdan et al., 1982). Peripheral plasma FSH concentrations increased from $1.67 \pm 0.28 \mathrm{ng} / \mathrm{ml}$ and $1.23 \pm$ $0.14 \mathrm{ng} / \mathrm{ml}$ on day -4 to reach a peak concentration of $4.13 \pm$ $0.53 \mathrm{ng} / \mathrm{ml}$ and $3.42 \pm 0.41 \mathrm{ng} / \mathrm{ml}$ on day 0 (day of oestrus) and decreased thereafter to $0.91 \pm 0.08 \mathrm{ng} / \mathrm{ml}$ on day 6 and $0.63 \pm 0.29 \mathrm{ng} / \mathrm{ml}$ on day 4 in buffaloes that exhibited overt oestrus and silent estrus, respectively, (S. Mondal, B. S. Prakash and P. Palta, unpublished data).

\section{Luteinizing hormone}

As also in case of cattle (Rahe et al., 1980), peripheral LH remain at basal levels throughout the oestrous cycle till the day of oestrus when a pre-ovulatory LH surge occurs. Whereas the baseline values hover around 0.72-3.0 ng/ml during a major part of the oestrus cycle, peak values of 20 $40 \mathrm{ng} / \mathrm{ml}$ have been observed on the day of oestrus (Sheth et al., 1978; Heranjal et al., 1979a; Kaker et al., 1980; Arora and Pandey, 1982; Kanai and Shimizu, 1984; Avenell et al., 1985). A similar pattern has also been observed in Swamp buffaloes (Kanai and Shimizu, 1984; Avenell et al., 1985). The interval from oestradiol peak to $\mathrm{LH}$ peak has been reported to be $14.8 \mathrm{~h}$ and the duration of LH peak to be 4.0 h (Batra and Pandey 1982/83). The interval between the LH surge and the onset of oestrus has been reported to be $8 \mathrm{~h}$ by Kumar et al. (1991). Kanai and Shimizu (1986) reported that LH surge occurred in association with behavioral oestrus in Swamp buffaloes and lasted for 7-12 h. Peak LH concentrations of $61-126 \mathrm{mg} / \mathrm{ml}$ were observed $4-15 \mathrm{~h}$ after the onset of oestrus whereas the interval between LH peak and the end of oestrus was much less variable. A direct positive feedback effect of oestradiol on LH secretion has not been demonstrated, however, occurrence of an oestradiol peak before the pre-ovulatory LH surge and a positive correlation between oestradiol and LH during the $24 \mathrm{~h}$ period before the LH surge (Kanai and Shimizu, 1986) indicate a role of oestradiol in mediating $\mathrm{LH}$ release. A pulsatile secretory pattern of LH has been demonstrated in buffalo (Aboul-Ela and Barkawi, 1988).

As also for many other hormones, peripheral LH levels are affected by season in buffalo. Peak LH levels have been found to be higher on the day of oestrus in cooler compared to those in the hotter months (Rao and Pandey, 1983) which may be due to inability of the hypothalamo-hypophyseal axis to produce a sustained increase in $\mathrm{LH}$ release in response to oestradiol. The frequency and amplitude of pulses during the follicular phase have been reported to be significantly higher during winter (frequency: 3.6 pulses $/ 8 \mathrm{~h}$, amplitude: $3.7 \mathrm{ng} / \mathrm{ml})$ than during summer season $(2.8$ pulses $/ 8$ h, 2.5 ng/ml, Aboul-Ela and Barkawi, 1988). Lower basal LH level and lack of pre-ovulatoy surge have 
been reported to be associated with ovarian inactivity and anoestrus condition during summer (Razdan and Kaker, 1980). In contrast, Kaker et al. (1980) observed similar mean peak LH concentrations at the time of oestrus in hot and cool months. As oestrus behavior is controlled either by accumulation of oestrogen in specific areas of hypothalamus (Clegg and Ganong, 1960; Radford, 1967) or by balanced plasma concentrations of oestradiol and progesterone (Karsch et al., 1980), the decrease in peak value of LH around oestrus together with decrease in progesterone concentrations (Rao and Pandey, 1982) may also be responsible for higher incidence of silent oestrus during summer.

\section{Prolactin}

Significantly higher peripheral plasma prolactin concentrations observed in various studies in summer than in winter season have been attributed to an influence of photoperiod on the pineal gland activities of prolactin controlling factors (Sheth et al., 1978; Heranjal et al., 1979b; Razdan and Kakar, 1980; Kaker et al., 1982; Galhotra et al., 1988). Besides photoperiod, ambient temperature plays a pivotal role in affecting prolactin levels. The circadian variation in prolactin concentration was more pronounced in summer than in winter because of greater variation in ambient temperature between morning, noon, evening and night during summer than winter. High prolactin levels during the summer season are believed to interfere with the oestrous cycle and fertility because prolactin a) directly affects ovarian steroidogenesis by altering the number of $\mathrm{LH}$ receptor and b) blocks the episodic release of LH from the hypothalamic and inhibits the positive feedback effects of oestrogens on LH secretion.

An effect of lactation on prolactin was reported by Singh and Madan (1993) who found that during summer, prolactin levels were higher in nonlactating than in lactating buffaloes whereas during winter, the levels were lower in nonlactating females than in lactating buffaloes. Parity has also been found to influence peripheral prolactin concentrations, which have been reported to be higher on the day of oestrus in multiparous buffaloes than in primiparous buffaloes (Pahwa and Pandey, 1984). These authors observed prolactin concentrations in milk to be higher compared to those in plasma suggesting a possible transfer of prolactin from plasma to milk.

\section{Prostaglandins}

A considerable individual variation, with mean $\mathrm{PGF}_{2 \alpha}$ levels ranging from 68.8 to $95.2 \mathrm{pg} / \mathrm{ml}$ and a non-significant increase 2 days before the onset of oestrus in buffaloes returning to oestrus but not in pregnant buffaloes was reported by Batra and Pandey (1983a) in one of the early studies. The concentrations of $\mathrm{PGF}_{2 \alpha}$ in milk were significantly higher, paralleled and were positively correlated with those in blood plasma during oestrous cycle and early pregnancy. Jain and Pandey (1991) observed that there were differences in $\mathrm{PGF}_{2 \alpha}$ concentrations on different days in pregnant buffaloes.

In another study, these authors reported that the concentrations of 15-keto-13,14-dihydro- $\mathrm{PGF}_{2 \alpha}$ (PGFM), a stable metabolite of $\mathrm{PGF}_{2 \alpha}$, remained at basal levels (200$250 \mathrm{pg} / \mathrm{ml}$ ) during oestrous cycle and increased to a peak value of $913 \mathrm{pg} / \mathrm{ml} 48 \mathrm{~h}$ before the onset of oestrus (Batra and Pandey, 1983b). The temporal changes of PGFM concentration at the time of luteolysis revealed that PGFM concentrations fluctuated dramatically with a major peak occurring $43.83 \pm 1.30 \mathrm{~h}$ before onset of estrus. Since administration of PGFM resulted in occurrence of oestrous 2-4 days after injection, the peak PGFM concentration before oestrus is a reflection of elevation of endogenous PGFM responsible for the regression of corpus luteum. PGFM concentrations in milk increased simultaneous with the increase in blood plasma.

\section{Cortisol, testosterone, $\mathbf{T}_{3}$ and $\mathbf{T}_{4}$}

Peripheral plasma cortisol levels have been reported to be high on the day of oestrus with reported peak concentrations ranging from 2-7 ng/ml (Kumar et al., 1991) to $5.07 \pm 0.38 \mathrm{ng} / \mathrm{ml}$ (Madan et al., 1993). These high levels may be due to stress caused by increased physical activity and also due to stress of oestrus. Singh and Madan (1985) reported that the mean testosterone concentrations which were $0.05 \pm 0.02 \mathrm{ng} / \mathrm{ml}$ on the day of oestrus remained at almost similar levels up to day 5 of the cycle. Peak concentrations of $0.10 \pm 0.04$ and $0.10 \pm 0.02 \mathrm{ng} / \mathrm{ml}$ were observed on day 8 and 9 , respectively, followed by a sharp decline to $0.05 \pm 0.02 \mathrm{ng} / \mathrm{ml}$ on day 10 post oestrus. Testosterone levels stayed low thereafter up to day 17 of the cycle.

Mean plasma $T_{3}$ concentrations have been reported to vary between $0.84 \pm 0.16$ and $1.88 \pm 0.10 \mathrm{ng} / \mathrm{ml}$ and $\mathrm{T}_{4}$ concentrations between $33.28 \pm 5.08$ and $50.76 \pm 8.23 \mathrm{ng} / \mathrm{ml}$ during the oestrous cycle (Khurana and Madan, 1985). During oestrous cycle, the highest serum protein bound iodine (PBI) has been found at the beginning of oestrus, which fell close to the time of ovulation, with Plasma $T_{3}$ levels low during late oestrus and metoestrus phase compared to prooestrus phase (Vadodaria et al., 1978). The highest $\mathrm{T}_{3}$ and $\mathrm{T}_{4}$ levels observed on the day of oestrus may be due to stress of oestrus. Lowest thyroid gland activity has been reported to occur during summer whereas moderate activity prevailed during the peak breeding period in winter by Vadodaria et al. (1978) who also found that the hypo (summer) or hyper (monsoon) activity of thyroid gland was associated with deranged reproductive behaviour, suboptimal follicular development, low FSH and FSH/LH 
ratio and high prolactin levels. $T_{3}$ and $T_{4}$ levels have been reported to be significantly higher in cycling buffalo heifers compared to anoestrus heifers (Sarvaiya and Pathak, 1992). Borady et al. (1987) reported a fall in thyroid hormones in Egyptian buffaloes exhibiting silent estrus.

Whereas ample information is now available on the status of oxytocin, estrogen, progesterone and $\mathrm{GnRH}$ receptors in cattle (Meyer et al., 1986; Kawate et al., 1991), the status of these hormone receptors is not known in buffalo. Binding analysis of $\left[{ }^{3} \mathrm{H}\right]$ progesterone to endometrial cytoplasmic receptors has revealed that total cytoplasmic progesterone receptors increased from the stage-II of oestrous cycle (days 5-10) through the stage-III (days 11-17) to the highest concentrations during stage-IV (days 18-20) after which there is a decline during stage-I of cycle (days 1-4, Mondal et al., 2001, 20002; 2002c) The decline in progesterone receptor levels during the stage-II of cycle may be due to exposure of uterus to increased levels of progesterone and decreased levels of oestrogen (Mondal et al., 2003, 2004). Preliminary studies on $\left[{ }^{3} \mathrm{H}\right]$ oestradiol binding to endometrial cytoplasmic receptors have indicated that the oestradiol receptor concentrations were higher during the follicular phase compared to those in the luteal phase probably due to rising concentrations of oestradiol in peripheral plasma shortly before oestrus. Low receptor concentrations during the later half of oestrous cycle may reflect saturation of the available binding sites by the prooestrus oestrogen surge. Progesterone may either reduce the uptake of oestrogen by the cell nucleus or it may affect the later stages of receptor protein synthesis once oestradiol has entered into the nucleus.

\section{CONCLUSIONS}

The review focuses on the endocrinology of oestrous cycle in buffaloes. Although some basic information is now available on various hormones related to oestrous cyclicity in buffalo, information on pulsatile release of gonadotropins and steroid hormones, status and regulation of receptors for various hormones and the intricate relationship between hormonal interplay and follicular recruitment, growth and development, which can be vital for a better understanding of regulation of oestrous cyclicity in buffalo, is still not available. Such information would not only help solve some of the problems specific to buffalo viz. silent oestrus, poor expression of behavioural oestrus, late initiation of cyclicity post partum etc., it would also be valuable for the development of reproductive technologies tailor-made for this species.

\section{REFERENCES}

Arora, R. C. and R. S. Pandey. 1982. Plasma concentrations of progesterone, oestradiol-17 $\beta$ and luteinizing hormone in relation to repeat breeding in buffalo (Bubalus bubalis) Anim. Prod. 34:139-144.

Aboul, Ela and A. H. Barkawi. 1988. Pulsatile secretion of LH in cyclic buffalo heifer as affected by season and stage of oestrous cycle. In Proceedings of $11^{\text {th }}$ International Congress on Animal Reproduction and Artificial Insemination, Dublin, Ireland 2:3

Abilay, T. A., H. D. Johnson and M. L. Madan. 1975. Influence of environmental heat on peripheral plasma progesterone and cortisol during bovine oestrous cycle. J. Dairy Sci. 58:18361840.

Ahmed, A., S. P. Agarwal, V. K. Agarwal, S. A. Rehman and K. R. Laumas. 1977. Steroid hormones. Part II. Serum progesterone concentrations in buffaloes. Ind. J. Exptl. Biol. 15:591-593.

Avenell, J. A., Y. Saepudin and I. C. Fletcher. 1985. Concentrations of $\mathrm{LH}$ and progesterone in the peripheral plasma of Swamp buffalo cow (Bubalus bubalis) around the time of estrus. J. Reprod. Fertil. 74:419-424.

Bachalaus, N. K., R. C. Arora, A. Prasad and R. S. Pandey. 1979. Plasma levels of gonadal hormones in cycling buffalo heifers. Ind. J. Exptl. Biol. 17:823-825.

Baruselli, P. S., R. G. Mucciolo, J. A. Vistin, W. G. Viana, R. P. Arruda, E. H. Maduriera, C. A. Oliveira and J. R. Molero-Filho. 1997. Ovarian follicular dynamics during the oestrous cycle in buffalo (Bubalus bubalis). Theriogenol. 47:1531-1547.

Batra, S. K. and R. S. Pandey. 1982/83. Luteinizing hormone and oestradiol-17 $\beta$ in blood plasma and milk during oestrous cycle and early pregnancy in Murrah buffaloes. Anim. Reprod. Sci. 5:247-257.

Batra, S. K. and R. S. Pandey. 1983a. Prostaglandin $F_{2 \alpha}$ in blood plasma and milk of nonpregnant and pregnant buffaloes (Bubalus bubalis). Acta Endocrinologica 102:314-320.

Batra, S. K. and R. S. Pandey. 1983b. Relative concentrations of 13,14 dihydro- 15 keto-prostaglandin $F_{2 \alpha}$ in blood and milk of buffaloes during oestrous cycle and early pregnancy. J. Reprod. Fertil. 67:191-195.

Batra, S. K., R. C. Arora, N. K. Bachalaus and R. S. Pandey. 1979. Blood and milk progesterone in pregnant and nonpregnant buffalo. J. Dairy Sci. 62:1390-1393.

Batra, S. K., R. C. Arora, N. K. Bachalaus, G. S. Pahwa and R. S. Pandey. 1980. Quantitative relationships between oestradiol$17 \beta$ in the milk and blood of lactating buffaloes. J. Endocrinol. 84:205-209.

Borady, A. M. A., A. E. Asdelaal and H. A. M. Farghaly. 1987. Seasonal variation in thyroid hormones and reproduction in Egyptian water buffalo. Egypt. J. Anim. Prod. 25:82-92.

Burger, H. G. 1992. Inhibin. Reprod. Med. Rev. 1:1-20.

Clegg, M. T. and W. F. Ganong. 1960. The effect of hypothalamic lesions on ovarian function in the ewe. Endocrinol. 67:179-186.

Galhotra, M. M., M. L. Kaker and M. N. Razdan. 1985. Serum FSH levels of noncycling Murrah buffaloes. Ind. J. Anim. Sci. 55:73-74

Galhotra, M. M., M. L. Kaker, I. S. Lohan, S. P. Singal and M. N. Razdan. 1988. Thyroid and prolactin status in relation to production in lactating Murrah. In Proceedings of $2^{\text {nd }}$ World Buffalo Congress, New Delhi, India, Vol I: 32.

Gwazdauskas, F. C., W. W. Thatchar and C. J. Wilcox. 1972. Adrenocortocotropin alteration of bovine peripheral plasma 
concentrations of cortisol, corticosterone and progesterone. J. Dairy Sci. 55:1165-1169.

Heranjal, D. D., A. R. Sheth, R. Desai and S. S. Rao. 1979a. Serum gonadotropins and prolactin levels during oestrous cycle in Murrah buffaloes. Ind. J. Dairy Sci. 32:247-249.

Heranjal, D. D., A. R. Sheth, K. B. Wadedekar, R. Desai and S. S. Rao. 1979b. Serum gonadotropins and prolactin levels in anoestrus buffaloes. Ind. J. Dairy Sci. 32:383-385.

Jain, G. C. and R. S. Pandey. 1991. Circulatory levels of Prostaglandin $F_{2 \alpha}$ and progesterone following breeding in buffalo heifers. Buff. Bulletin 10:38-44.

Jainudeen, M. R., W. Sharifuddinn and F. Bashir Ahmed. 1983. Relationship of ovarian contents to plasma progesterone concentration in Swamp buffalo (Bubalus bubalis). Vet. Rec. 113:369-372.

Janakiraman, K., M. C. Desai, D. R. Amin, A. R. Sheth, S. B. Moodbidri and K. B. Wadadekar. 1980. Serum gonadotropin levels in buffaloes in relation to phases of oestrous cycle and breeding periods. Ind. J. Anim. Sci. 50:601-606.

Kaker, M. L., M. N. Razdan and M. M. Galhotra. 1980. Serum LH concentrations in cyclic buffalo (Bubalus bubalis). J. Reprod. Fertil. 60:419-424.

Kaker, M. L., M. N. Razdan and M. M. Galhotra. 1982. Serum prolactin levels of non cycling Murrah buffalo (Bubalus bubalis). Theriogenol. 17:469-474.

Kamboj, M. and B. S. Prakash. 1993. Relationship of progesterone in plasma and whole milk of buffaloes during cyclicity and early pregnancy. Trop. Anim. Hlth. Prod. 25:185-192.

Kamonpatana, M., Y. Luvira, P. Bodipaksha and A. Kunawongkrit. 1976. Serum progesterone, 17-hydroxy progesterone and 17 $\beta$ oestradiol during oestrous cycle in Swamp buffalo in Thailand. In Nuclear Techniques in Animal Production and Health, Vienna, Austria, International Atomic Energy Agency, pp. 569578.

Kanai, Y. and H. Shimizu. 1984. Plasma concentrations of LH, progesterone and oestradiol during oestrous cycle in Swamp buffaloes (Bubalus bubalis). J. Reprod. Fertil 70:507-510.

Kanai, Y. and H. Shimizu. 1986. Changes in the plasma concentration of luteinizing hormone, progesterone and oestradiol-17 $\beta$ during the periovulatory period in cyclic Swamp buffaloes (Bubalus bubalis). Anim. Reprod. Sci. 11:17-24.

Karsch, F. J., S. J. Legan, K. D. Ryan and D. L. Foster. 1980. Importance of oestradiol and progesterone in regulating $\mathrm{LH}$ secretion and oestrus behaviour during the sheep oestrous cycle. Biol. Reprod. 23:404-413.

Kawate, N., T. Inaba and J. Mori. 1991. Gonadotropin releasing hormone receptors in anterior pituitary of cattle during oestrous cycle. Anim. Reprod. Sci. 24:185-191.

Kaur, H. and S. P. Arora. 1984. Annual pattern of plasma progesterone in normal cycling buffaloes (Bubalus bubalis) fed two different levels of nutrition. Anim. Reprod. Sci. 7:323-332.

Khurana, M. L. and M. L. Madan. 1985. Thyroidal hormone during oestrous cycle in cattle and buffaloes. Ind. J. Dairy Sci. $38: 119-123$

Kumar, R., R. Jindal and P. J. S. Rattan. 1991. Plasma hormonal profiles during oestrous cycle of Murrah buffalo heifers. Ind. J. Anim. Sci. 61:382-385.

Madan, M. L., S. K. Das and P. Palta. 1996. Application of reproductive technology to buffaloes. Anim. Reprod. Sci. 42:299-306.

Madan, M. L., B. S. Prakash, S. Jailkhani, S. K. Singla, P. Palta and R. S. Manik. 1993. In: Buffalo endocrinology with special reference to embryo transfer. Embryo Biotechnology Centre, NDRI, Karnal, India, pp 32.

Manik, R. S., S. K. Singla, P. Palta and M. L. Madan. 1998. Ovarian follicular dynamics monitored by real-time ultrasonography during oestrous cycle in buffalo (Bubalus bubalis). Asian-Aust. J. Anim. Sci. 11:480-485.

Memon, G. N., N. C. Buch and B. M. Patel. 1971. A study of follicular and luteal characteristics of the ovary at different stages of oestrous cycle in Surti buffalo heifer. J. Reprod. Fertil. 27:301 (Abstr).

Meyer, H. H. D., J. Mittermeier and D. Schams. 1986. Dynamics of oxytocin, oestrogen and progesterone concentrations in the bovine endometrium during oestrous cycle. Acta Endocrinol. 118:96-104.

Mondal, S., P. Palta and B. S. Prakash. 2000a. Peripheral inhibin concentrations in relation to stage of oestrous cycle and progesterone in Sahiwal cows and Murrah buffaloes. In: Proceedings of $14^{\text {th }}$ International Congress on Animal Reproduction, Stockholm, Sweden, 1:209.

Mondal, S., B. S. Prakash and P. Palta. 2000b. Relationship between peripheral plasma inhibin and FSH in cycling Murrah buffaloes (Bubalus bubalis). J. Endocrinol. (Supp.) p. 167:67 (Abstr.)

Mondal, S., P. Palta and B. S. Prakash. 2001a. Influence of season on peripheral plasma progesterone in cycling Murrah buffaloes. In Proceedings of $29^{\text {th }}$ British Congress of Obstetrics and Gynaecology, Birmingham, UK, p. 177.

Mondal, S., B. S. Prakash and P. Palta. 2001b. Comparison of changes in peripheral plasma inhibin in relation to oestrous cycle between cows and buffaloes. In: Proceed. Br. Soc. Anim. Sci., London, UK, p. 221.

Mondal, S. and B. S. Prakash. 2002a. Peripheral plasma progesterone concentrations in relation to oestrus expression in Sahiwal cows and Murrah buffaloes. Reprod. Abstract Series No. 28:29-30 (Abstr.).

Mondal, S. and B. S. Prakash. 2002b. Peripheral plasma progesterone concentrations in relation to oestrus expression in Murrah buffalo (Bubalus bubalis). Ind. J. Anim. Sci. 73:292293.

Mondal, S. and B. S. Prakash. 2002c. Comparison of luteal function between cows and buffaloes during oestrous cycle. Ind. J. Dairy Sci. 55(3):142-144.

Mondal, S., P. Palta and B. S. Prakash. 2002a. Peripheral plasma inhibin concentrations in relation to overt and silent oestrus in Sahiwal cows and Murrah buffaloes. Biol. Reprod. (Supp 1) 66:261 (Abstr.).

Mondal, S., P. Palta and B. S. Prakash. 2002b. Peripheral plasma inhibin concentration in relation to oestrus expression in Murrah buffaloes. In: Proceedings of $89^{\text {th }}$ Session of Indian Science Congress Association, Lucknow, India, p. 64-65.

Mondal, S., Vijay Kumar, I. J. Reddy and Khub Singh. 2002c. Endometrial cytosolic progesterone receptor concentrations in relation to phases of oestrous cycle in buffalo. In Proceedings of $89^{\text {th }}$ Session of Indian Science Congress Association, Lucknow, India, pp. 67-68 (Abstr.).

Mondal, S., Vijay Kumar, I. J. Reddy and Khub Singh. 2001. 
Department of Agricultural Research and Education Annual Report, ICAR, New Delhi, p. 116.

Mondal, S., B. S. Prakash and P. Palta. 2003a. Relationship between peripheral plasma inhibin and progesterone concentrations in Sahiwal cattle (Bos indicus) and Murrah buffaloes (Bubalus bubalis). Asian-Aust. J. Anim. Sci. 16(1):610.

Mondal, S., B. S. Prakash and P. Palta. 2003b. Peripheral plasma inhibin concentrations in relation to expression of oestrus in Murrah buffaloes (Bubalus bubalis). Ind. J. Anim. Sci. 73(4):405-407.

Mondal, S., Vijay Kumar, I. J. Reddy and Khub Singh. 2003-2004. Department of Agricultural Research and Education Annual Report, ICAR, New Delhi, p. 119.

Mondal, S., P. Palta and B. S. Prakash. 2004a. Influence of season on peripheral plasma progesterone in cycling Murrah buffaloes (Bubalus bubalis). Buff. J. 1:95-100.

Mondal, S., Vijay Kumar, I. J. Reddy and Khub Singh. 2004 b. Progesterone and nucleic acid content of buffalo corpus luteum in relation to stages of oestrous cycle. Ind. J. Anim. Sci 74(6):710-712.

Pahwa, G. S. and R. S. Pandey. 1983. Gonadal steroid hormone concentrations in blood plasma and milk of primiparous and multiparous pregnant and non pregnant buffaloes. Theriogenol. 19:491-505.

Pahwa, G. S. and R. S. Pandey. 1984. Prolactin in blood plasma and milk of buffalo during oestrous cycle and early pregnancy. J. Dairy Sci. 67:2001-2005.

Palta, P., S. Jailkhani, B. S. Prakash, R. S. Manik and M. L. Madan. 1996a. Development of direct radioimmunoassay for oestradiol-17 $\beta$ determination in follicular fluid from individual buffalo ovarian follicles. Ind. J. Anim. Sci. 66:126-130.

Palta, P., B. S. Prakash and M. L. Madan. 1996b. Peripheral inhibin levels during oestrous cycle in Murrah buffalo (Bubalus Bubalis). Theriogenol. 45:655-664

Palta, P., B. S. Prakash, R. S. Manik and M. L. Madan. 1996c. Inhibin in individual buffalo ovarian follicles in relation to size. Ind. J. Exptl. Biol. 34:606-608.

Palta, P., S. Mondal, B. S. Prakash and M. L. Madan. 1997. Peripheral plasma inhibin levels in relation to climatic variation an stage of oestrous cycle in buffalo (Bubalus bubalis). Theriogenol. 47:989-995.

Palta, P., N. Bansal, B. S. Prakash, R. S. Manik and M. L. Madan. 1998a. Interrelationship between follicular size and follicular fluid estradiol-17 $\beta$, progesterone and testosterone concentrations in individual buffalo ovarian follicles. Asian-Aust. J. Anim. Sci. 11:293-299

Palta, P., N. Bansal, B. S. Prakash, R. S. Manik and M. L. Madan. 1998b. Follicular fluid inhibin in relation to follicular diameter and oestradiol-17 $\beta$, progesterone and testosterone concentrations in individual buffalo ovarian follicles. Ind. J. Exptl. Biol. 36:768-774

Palta, P., N. Bansal, B. S. Prakash, R. S. Manik and M. L. Madan. 1998c. Endocrinological observation of atresia in individual buffalo ovarian follicles. Ind. J. Anim. Sci. 68:444-447.
Parmar, A. P. and V. M. Mehta. 1994. Seasonal endocrine changes in steroid hormones of developing ovarian follicles in Surti buffaloes. Ind. J. Anim. Sci. 64:111-113.

Prakash, B. S., P. Palta, N. Bansal, R. S. Manik and M. L. Madan. 1997. Development of a sensitive direct enzymeimmunoassay for progesterone determination in follicular fluid from individual buffalo follicles. Ind. J. Anim. Sci. 67:36-38.

Radford, H. M. 1967. The effect of hypothalamic lesions on reproductive activity in sheep. J. Endocrinol. 39:415-422.

Rahe, C. H., R. E. Owens, J. L. Fleiger, H. J. Newton and P. G. Harms. 1980. Pattern of plasma luteinizing hormone in the cyclic cow: Dependence upon the period of the cycle. Endocrinol. 107:498-505.

Rao, L. V. and R. S. Pandey. 1982. Seasonal changes in the plasma progesterone concentration in buffalo cow (Bubalus bubalis). J. Reprod. Fertil. 66:57-61.

Rao, L. V. and R. S. Pandey. 1983. Seasonal variations in oestradiol-17 $\beta$ and luteinizing hormone in the blood of buffalo cows (Bubalus bubalis). J. Endocrinol. 98:251-255.

Razdan, M. N. and M. L. Kakkar. 1980. Summer sterility and endocrine profiles of buffaloes. Ind. Dairyman 32:459-464.

Razdan, M. N., M. L. Kaker and M. M. Galhotra. 1982. Serum FSH levels during oestrus and a 4-week period following mating in Murrah buffaloes (Bubalus bubalis). Theriogenol. $17: 175-181$

Samad, H. A., H. Hamid and N. V. Rehman. 1988. Plasma oestradiol-17 $\beta$ concentrations during oestrous cycle of NiliRavi buffaloes. In: Proceedings of $11^{\text {th }}$ International Congress on Animal Reproduction and Artificial Insemination held at Dublin, Ireland, p. 2:3.

Sarvaiya, N. P. and M. M. Pathak. 1992. Profiles of progesterone, 17 $\beta$-oestradiol, triiodothyronine and blood biochemical parameters in Surti buffalo. Buff. J. 8:23-30.

Shah, R. G. and V. M. Mehta. 1992. Correlated behaviour of blood and corpus luteum progesterone levels with luteal cell types in Surti buffaloes. Buff. J. 8(2):167-173.

Sheth, A. R., K. B. Wadadekar, S. B. Moodbidri, J. Janakiraman and M. Parameshwardan. 1978. Seasonal alteration in serum prolactin and LH levels in water buffalo. Current Sci. 47:75-77.

Singh, M. and M. L. Madan. 1985. Plasma testosterone during oestrous cycle and post partum period among buffaloes. Ind. J. Anim. Reprod 6:13-16.

Singh, J. and M. L. Madan. 1993. RIA of prolactin as related to circadian changes in buffaloes. Buff. J. 9:159-164.

Vadodaria, V. P., K. Janakiraman and N. C. Buch. 1978. Thyroid activity in relation to reproductive performance of Surti buffalo heifers (Bubalus bubalis)-protein bound iodine. Ind. J. Exptl. Biol. 16:986-988.

Wagner, W. C., R. E. Strohbehn and P. A. Harris. 1972. ACTH, corticoids and luteal function in heifers. J. Anim. Sci. 35:789793.

Wettemann, R. P., H. D. Hafs and L. A. Edgarton. 1972. Estradiol and progesterone in blood serum during the bovine estrous cycle. J. Anim. Sci. 34:1020-1025. 